\title{
Ecocritical Concerns in Select Afrikaans Narrative Works: Critical Perspectives
}

\section{Susan Meyer}

To cite this article: Susan Meyer (2021) Ecocritical Concerns in Select Afrikaans Narrative Works: Critical Perspectives, Journal of Literary Studies, 37:4, 84-105, DOI: 10.1080/02564718.2021.1997169

To link to this article: https://doi.org/10.1080/02564718.2021.1997169

\section{Published online: 02 Dec 2021}

Submit your article to this journal $\square$

Q View related articles ¿

View Crossmark data 


\section{Ecocritical Concerns in Select Afrikaans Narrative Works: Critical Perspectives}

\section{Susan Meyer}

\section{Summary}

Environmentally oriented literary and cultural studies, or ecocriticism for short, gained traction in the United States of America in the late 1980s. It took root in South Africa no earlier than the start of this century and has been applied to the field of Afrikaans literature only for about the last decade. At a conference in Nijmegen in 2010, the leading German ecocritic Axel Goodbody expressed concern about the slow spread of ecocriticism to non-Anglophone literatures. He highlighted the debilitating effect of the hegemony of English as medium of communication on practising ecocriticism. Goodbody warned that ecocritic debates would be poorer if they neglect the resources of theorising and critical analyses in non-English-speaking language and other contexts; and cultures that are not dominated by Anglophone traditions.

Afrikaans has been part of the surge of different national voices and languages in this field. This article enters the debate about the expansion of ecocritical studies to include a more environmentally oriented world of research than the one dominated by Anglophone literatures for quite a few decades. It offers a critical-descriptive overview of how ecocritical studies centred on Afrikaans literary narratives add nuances to and amplify thematic matters of interest for ecocriticism in our country. I want to highlight the diverse and convincing contributions made by Afrikaans literary critics to "the understanding of the human relationship to the planet" (Joni Adamson \& Scott Slovic, 2009: 6). These contributions are analysed in order to also evaluate the relevance of the various theoretical angles of approach in use, regarded within the broader theoretical discourse of ecocriticism.

\section{Opsomming}

Omgewingsgeoriënteerde literêre en kulturele studies, of kortweg, ekokritiek, het in die laat 1980's steun verwerf in die Verenigde State van Amerika. Dit het egter eers aan die begin van hierdie eeu in Suid-Afrika ingewortel geraak en word maar sowat vir die laaste dekade in die veld van Afrikaanse literatuur toegepas. Die gesaghebbende Duitse ekokritikus Axel Goodbody het op 'n konferensie in Nijmegen in 2010 sy besorgdheid oor die stadige verspreiding van ekokritiek na nie-Engels-sprekende literature uitgespreek. Hy het die verlammende uitwerking van die hege-monie van Engels as kommunikasiemedium op die beoefening van ekokritiek beklemtoon. Goodbody het gewaarsku dat debatte oor ekokritiek armer sal wees indien hulle die hulpbronne van teoretisering en kritiese ontleding in nie-Engels-sprekende taal- en ander kontekste, en kulture wat nie deur Engelssprekende tradisies oorheers word nie, verwaarloos. 
Afrikaans was deel van die oplewing van verskillende nasionale stemme en tale in hierdie veld. Hierdie artikel sluit aan by die debat oor die uitbreiding van ekokritiese studies, om 'n meer omgewingsgeoriënteerde wêreld van navorsing in te sluit as die een wat vir 'n hele paar dekades deur Engelssprekende literature oorheers is. Dit bied 'n kritiese-beskrywende oorsig van hoe ekokritiese studies wat op Afrikaanse literêre verhale fokus, tematiese wetenswaardighede vir ekokritiek in ons land toelig en nuanses daartoe byvoeg. Ek wil klem lê op die uiteenlopende en oortuigende bydraes van Afrikaanse literêre kritici tot "die verstaan van die menslike verhouding tot die planeet" (Joni Adamson \& Scott Slovic, 2009: 6). Hierdie bydraes word ontleed om ook die toepaslikheid van die verskillende teoretiese invalshoeke in gebruik te evalueer, beskou binne die breër teoretiese diskoers van ekokritiek.

\section{Introduction and Context}

Until about a decade ago, environmentally oriented literary and cultural studies, or ecocriticism for short, ${ }^{1}$ was limited largely to the US, and in Europe to the UK. At a panel discussion during a conference in Nijmegen in the Netherlands ${ }^{2}$ in 2010 , there was excitement about the expansion of ecocritical studies to include a wider front, as evident from the founding of chapters of the Association for the Study of Literature and Environment (ASLE) on different continents, and by the founding of the World Ecoculture Organisation (WEO) in 2009 (Flys 2010: 109).

However, African and Indian ecocritics and several others from Asian countries made clear, at the conference where the WEO was founded, ${ }^{3}$ that although ecocriticism was evidently transforming into an international discursive formation, it was not necessarily open to their voices in a satisfactory way (Oppermann 2012: 408). At the Nijmegen conference members of the mentioned panel explicitly supported the point of ecocriticism

1. In the seminal The Routledge Dictionary of Literary Terms ecocriticism is defined as " $\mathrm{t}]$ he study of literary texts with reference to the interaction between human activity and the vast range of 'natural' or non-human phenomena which bears upon human experience - encompassing (amongst many things) issues concerning fauna, flora, landscape, environment and weather" (Childs \& Fowler 2006: 65).

2. The conference was titled: "New Grounds: Ecocriticism, Globalization and Cultural Memory", and organised by the University of Nijmegen. The topic of the panel discussion was "The state of ecocriticism in Europe".

3. The WEO came into being during the International Conference on "Ecological Literature and Environmental Education: Asian Forum for Cross-cultural Dialogues", at Beijing University in China, in August 2009. The central aim of this organisation is to bring into ecocritical focus the non-Western literatures and cultures, and to offer a platform for international ecocritics to carry into this domain ecoliterary paradigms that are not US-centric (Oppermann 2012: 408). 
being far from open to all voices. They offered statistics to show English dominating nearly all the European conferences as a medium of communication at the time. The question emerged: In future, will ecocriticism spread to the non-English-speaking world? To what extent, actually, is ecocriticism practised in other languages? (Flys 2010: 110).

Axel Goodbody, leading authority on German environmental literature, highlighted the debilitating effect of the hegemony of English as medium of communication for practising ecocriticism. He warned that debates in ecocriticism would be poorer when neglecting the sources of ecological theorising and critical analyses in non-English-speaking languages, and in contexts and cultures not dominated by Anglophone traditions (reported by Flys 2010: 111).

In discussing the transnationalisation ${ }^{4}$ of ecocriticism Serpil Opperman (2012: 402) remarks that ecocriticism, with its transnational expansion in recent times, signals a rethinking of the local. This concept inevitably includes rethinking the topic of (local) place and issues linked to and representative of place. A decade later, Afrikaans has become part of the surge of different national voices and languages to broaden and strengthen the work of nonAnglophone literary ecocriticism. However in small numbers a few critics of the Afrikaans literature started following ecocriticism's primary interest in place-based critical inquiry and in narratives of the local.

The focus of this article is on the ecocritical research done in the domain of Afrikaans literature of place. The objective is to offer a critical-descriptive overview of how Afrikaans ecocritical practice lays bare the diversity and the nature of place-based themes in Afrikaans literature. From a list of the most extensively researched topics of place and issues associated with place in Afrikaans literature, I critically consider the ecocritical research done on the two most significant ones. This is planned for the next two sections. In doing so, I also analyse the theoretical point of reference the critics departed from and indicate how ecocritical research on Afrikaans literature theoretically relates to ecocritical work globally.

I do not intend to claim that the representations of place and the views on matters concerning place in Afrikaans literature will reveal this being done in ways not done by English writers in South Africa. Such a claim would include that I should offer comparative illustrations, which is not in line with the aims spelled out above. I rather accentuate the presence and the vigour of this young voice, Afrikaans, with its ecocritical attentiveness to local notions of place. This critical-descriptive overview testifies to the amplifying effect of

4. Concerning the transnationalisation of ecocriticism: Serpil Oppermann (2012: 412) reminds us that, from the perspective of an increasingly globalised world - not only in terms of human mobility and capital flow, but also with regard to the overwhelming planetary ecological problems - the borderlines between literatures and cultures within and across countries and continents have become less and less distinct. 
Afrikaans ecocritics' diligence (however these critics are a very small number) on South(ern) African environmentally oriented literary studies and exposes the shades of meaning brought about by ecocritical interpretations of place in Afrikaans literature. My critical consideration of the mentioned research also elucidates the sophisticated theoretical undertone in the Afrikaans ecocritical voice - engaged, together with its historically stronger companion voice in die South(ern) African literary criticism, in the broad conversation on how the "vast range of 'natural' or non-human phenomena which bears upon (our) human experience" (Childs \& Fowler 2006: 65) is portrayed.

So the intention with this article rather is to extend the Nijmegen-debate by paying special attention to the invigorating effect brought to ecocriticism by ecological theorising and critical analyses in a non-English-speaking language, on this part of the global sphere, with our widely differing geographic conditions and our unique variety of wild and tame animals, birds and insects.

It is important to note that although ecocriticism gained traction in the USA in the late 1980s, it reached South Africa no earlier than the start of this century, and it has been used as a lens in critical reading Afrikaans literature only in the last decade. ${ }^{5}$

Paradoxically, works portraying human interest in nature, and lives intertwined with nature, count among the very first published Afrikaans literary texts - such as farm novels - yet ecocritical studies have been on the margin of Afrikaans literary world until about eight years ago (Smith 2014a). In 2013 Andries Visagie predicted that more Afrikaans literary critics will join Susan Meyer and Susan Smith in tackling ecocritical challenges, but a noticeable growth in the number of ecocritical studies on our literature has been observed only since 2018 (Fourie 2018: 1011). ${ }^{6}$

The five themes most extensively researched by ecocritical readings of Afrikaans narrative works, according to my close observations and judgement as an active ecocritic in this domain, are listed below.

Firstly, Afrikaans literature of place wittingly raises issues of human interaction with nature - with the non-living and the living non-human - from a critical stance and in various ways.

5. In South Africa the first steps towards an ecocritical approach to literature was taken in 1999 by Julia Martin. She "introduced" this path by calling it the theory and practice of "environmental literacy". The first literary critics who followed her were working in the field of English literature, but since around 2010 a few voices behind critical studies in Afrikaans literature have joined the ecocritical discourse.

6. Viljoen (2019: 121) mentions the contributions of Erika Lemmer, Susan Smith, Susan Meyer, Marius Crous, Andries Visagie, Joan-Mari Barendse en Adéle Nel to the ecocritical readings of Afrikaans literary texts. 
Secondly, Afrikaans literature focuses on depicting natural surroundings as intimate personal places, and here place is linked to a sense of human identity.

In the third instance, Afrikaans authors turn to the ethical aspects of ecocriticism to point out - and hopefully to counteract - our catastrophic belief in Western master narratives of human supremacy, putting at risk our planet's life-sustaining systems.

The fourth aspect includes the positive role of nature and the natural environment in human wellbeing.

In the fifth place, Afrikaans literature of place tries to demonstrate how historical development and cultural frames form part of the meanings of landscape down here at the tip of Africa.

In the next sections of the article the focus turns to the first two identified themes. Here an inevitable shortcoming in the article needs to be mentioned. This article practically allows for critically considering the ecocritical research on only the first two themes. Covering all the themes would be too comprehensive a task - considering the importance of also evaluating the relevance of the various ecocritical points of reference ecocritics in Afrikaans literature have departed from, seen within the global theoretical context of ecocriticism.

Furthermore, the discussion following is not an attempt to comment on all the ecocritical work done on these first mentioned topics. Rather, the focus is on a selection of texts that is representative of how various researchers' work intersects and mutually confirms one another's views and findings, or differ on these. Outlining the two most significant ecocritical topics in Afrikaans literature presents a start in discovering the multiplicity and diversity added to ecocritical interpretations by another tongue than the Anglophone one, and may be a boost for further investigation of other ecocritical topics in Afrikaans narrative art.

Shades of meaning brought by ecocritical interpretations of place in Afrikaans literature.

\section{Theme One: Interaction with the Living Non-human and the Non-living}

Animals are of growing importance in literary studies worldwide. In following this international "animal turn", ${ }^{7}$ Afrikaans literary studies have aimed to subvert the binary opposition between human and animal grounded so deeply in our Western political and pragmatic selves. Gross (2012: 12)

7. Greg Garrard (2012: 146) explains that studies grounded in the "animal turn" focus on two aspects: the representation of animals in history and cultural contexts and the philosophical contemplation on animal rights. 
reckons this ontological divide affects crucial every day issues like food security, gender roles, and basic justice.

Animal studies, ${ }^{8}$ named human-animal studies by critics like Marvin and McHugh (2014: 2-5) as well as Woodward and Lemmer (2014: 2), sheds new light on how we give voice to animals and to experiences beyond our understanding; how we should observe differences without any processes of appropriating or distortion; and how we should acknowledge the interwovenesss of animal and human lives (Weil 2012: 6-7). ${ }^{9}$ Literary studies based on the theoretical framework of human-animal studies - a multi- and transdisciplinary field - generally overlap with the theories of ecocriticism and other disciplines, like posthumanism and postcolonialism. (See for instance Wolfe 2003, 2010; Taylor \& Twine (2014); and Visagie (2013). Hence scholars of human-animal studies often regard their work to be directly linked to ecocriticism.

Literary critic Marius Crous approaches a poem of N.P. Van Wyk Louw's volume Nuwe verse ("New Poems"), originally published in 1954 and titled "Beeld van 'n jeug: duif en perd" ("Image of a Youth: Dove and Horse"), through the lens of animal studies (Crous 2016b). In Van Wyk Louw's poems animals have often been interpreted as symbols conveying complex symbolic issues, but by Crous's alternative reading strategy the bird in "Beeld van 'n jeug: duif en perd" is also foregrounded in an attempt to undermine the

8. A clear and concise description of human-animal studies is supplied in the online preview of the Routledge Handbook of Human-Animal Studies: "Human-animal studies explores the whys, hows, and whats of human-animal relations: why animals are represented and configured in different ways in human cultures and societies around the world; how they are imagined, experienced, and given significance; what these relationships might signify about being human; and what about these relationships might be improved for the sake of the individuals as well as the communities concerned." (Marvin \& McHugh 2014?) (More information about the provenance and directions of human-animal studies is to be found in the Routledge Handbook of HumanAnimal Studies, edited by G. Marvin and S. McHugh).

9. The notion of the intertwined existence of animals and humans, that Weil (2012: 6-7) refers to, is key to the intellectual movement of the new materialism. Ecocritics who favour the material turn (see footnote 20 for information on the material turn), view material reality as affecting all dimensions of life - the human and the non-human - and focus on the physical and interactive connection between living and non-living things. The theoretical framework of the new materialism has been used in various ecocritical studies on Afrikaans literature, mainly in exploring authors' focus on humans' destructive dealing with nature and nature resources. Since this theme is the third one of interest for ecocritical research in Afrikaans narrative art (as listed in the introductory section), the use of new materialism's theories in our literature will have to be examined in a follow-up study. 
Cartesian view of humanity, which implies denigrating an animal to an "it". (Crous 2016b: 43) The boy in this poem finds himself in a decentralised situation, with the dove in the centre of his flight of imagination. The bird no longer functions as a symbol only - the boy is caught up in its actions and loses himself in a flight of fancy where he himself is no longer in the centre of his imagination, but the dove is. Furthermore, Crous finds in this poem a process of becoming-animal in the way Deleuze and Guattari (1987: 237) used this concept, referring to a reciprocal process of "desubjectifying and designification, that explodes the human-animal dualism and configures [...] out of its debris, an identity fluctuating along the constantly changing dynamic of becoming, not firmly based on the ontological stability of being" (Heymans 2011). Crous's scrutiny of "Beeld van 'n jeug: duif en perd" yields clear signs of the boy's becoming-dove; in this poem none ontological stability is left, only a questioning of the dualistic thinking about human and bird (Crous 2016b: 43).

In another study Crous analyses "Postmoderne hadeda" ("Postmodern hadedah" [Hadeda Ibis]), a poem from Marlene van Niekerk's volume Kaar, and accentuates Van Niekerk's posthuman and non-anthropocentric view on animals (Crous 2016a: 210). Here the hadedah, as observed by the poet, serves as a metaphor for the creative act and in particular post-modernist writing. Crous (2016a: 210) highlights the poet's post-anthropocentric fascination and admiration in her process of describing the hadedah. After the bird has entered the poet's writing space, it is no longer considered the intrusive Other, but becomes central to her contemplation on writing. The poet's infatuation while observing the bird results in giving herself over to the hadedah, which plays a pivotal role in her poetic experience. Crous (2016a: 211) follows Deleuze and Guattari again in discussing the poet's process of crossing the boundary between herself and the animal, of "becoming-hadedah". He concludes with Deleuze and Guattari (1978: 240) words: "If the writer is a sorcerer, this is because to write is to become, to write is traversed by strange becomings, which are not becomings-writer but becomings-rat, becomings-insect, becomings-wolf, etc."

In 2012, Johann Lodewyk Marais follows Marius Crous in rereading a number of N.P. van Wyk Louw's poems on animals. ${ }^{10}$ However, in "Wyk Louw se diere en gestaltes herbesoek: 'n ekokritiese lesing" ("N.P. van Wyk Louw's Animals and Figures: An Ecocritical Reading") (2020) Marais approaches his ecocritical rereading from a different angle. He concentrates on Van Wyk Louw's close attention to the species-specific features of mammals and to the crucial role information sources from the world of natural

10. The directions taken by Louw's poetry have been studied by several literary critics who have picked up hints of modernism (see Cloete 1963: 1-20; Van Heerden \& Visagie 2013; Voss 2012: 339-359), simbolism (see Van Rensburg 1993: 495-515) and postmodernism (see Peter Bürger (1992: 33)). 
sciences played in creating poems like "Die strandjutwolf" ("The Brown Hyaena" [Hyaena brunnea]) and "Die swart luiperd" ("The Black Leopard" [Panthera Pardus]) from Gestaltes en diere ("Figures and Animals"). ${ }^{11}$

Marais's attention to Van Wyk Louw's emphasis on the biologic features of animals in his poetry of the early 1940s spotlights a break with the undifferentiated and monotonous way of depicting the world of animals, by today's standards; the concepts of uniqueness and distinctiveness clearly were valued by the poet (Marais 2020: 447). By adding new views to the discourse on animal studies Marais finds new relevance in Van Wyk Louw's work within the context of ecocriticism in Afrikaans literature, and within a context in which "[e]environmentalism's postcoloniality is registered in [...] the very discourse and practice of the preservation of the "natural order of species in the wake and face of change"' (Casid 2012: 64; see Marais 2020: 447).

In two related studies Joan-Mari Barendse and Bibi Burger investigate the representation of insects in Afrikaans literature. These studies involve the analysis of different texts, either of them thematically corresponding with the overarching goal of human-animal studies, namely "to study animals with humans, and humans with animals, never forgetting that we are both animals in general, and humans in particular" (Marvin \& McHugh 2014: 2).

Both Barendse and Burger exploit Deleuze and Guattari's theory on the concept of becoming-animal, in respective texts by Willem Anker: the play Samsa-masjien ("Samsa machine") (2015) and the novel Siegfried (2007). Barendse explores processes of gradually crossing the boundary between being human and being insect, visible in the main character of Samsa-masjien who, at last, even communicates by means of uninterpretable sounds instead of words. Burger finds that in the representation of the disabled character Siegfried in the eponymous novel there are traces of Deleuze's and Guattari's becomings as well - lines of flight from blocked forms of human subjectivity. In this novel the portrayal of Siegfried's interaction with the more-thanhuman effectively deconstructs dominant views on active human subjects and passive non-human objects.

Louise Viljoen's close look at the representation of the dog in Breyten Breytenbach's poetry (Viljoen 2019) partly relates to research on the earlier work of N.P. van Wyk Louw, focusing on the symbolic meaning of poems about animals, ${ }^{12}$ and with little attention paid to specific species with unique

11. According to J.C. Steyn, Louw's autobiographer, scientific sources like Die soogdiere van die Suider-Afrikaanse substreek ("Mammals from Southern Africa"), by R.H.N. Smithers, were intensively drawn into the process of creating these poems (Marais 2020: 440, 445).

12. Marais (2019: 436) links these interpretations to the symbolic and modernist trend in Louw's earlier works. Wilhelm Liebenberg (1991: 7), points out that modernism was pushed aside by postmodernism in Van Wyk Louw's work in 
features. Regarding the poem "Koop 'n hond" ("Buy a Dog") from Die beginsel van stof ("The Principle of Dust") (2012) Viljoen expertly elaborates on the animal functioning as a trope or metaphor (Viljoen 2019: 126, 140) - particularly the dog with its symbolic links to the process of artistic creativity, or the activities of the poet's hand. ${ }^{13}$ But, she then argues, there are moments in Breytenbach's work where the dog is a real and living animal with agency, emotions, and the ability to recognise death (Viljoen 2019: 145). Viljoen hereby follows fellow citizen and ecocritic Wendy Woodward, who prefers understanding animals as "sentient beings with their own individualities and their own contribution to the plot" (Woodward 2008: 16) ${ }^{14}$ Viljoen highlights the importance of "Koop 'n hond", a poem revealing traces of the poet's acknowledgement that using animals as metaphors implies a form of human authority. The poem offers a glance at an animal breaking through the straitjacket of the trope and, for a moment, is manifesting as living being in its own right - with individuality and sentience (Viljoen 2019: 148).

In the collection of scholarly papers, Dogs in Southern African Literatures (2018), a few contributors join Viljoen in critically examining the representation of dog as a literary symbols, and in making Afrikaans novels part of their field of inquiry. Gerda Taljaard-Gilson includes a variety of older and more recent Afrikaans literary texts, aiming at discovering the ambivalent portrayal of canines in them: Wolftyd ("Time of the Wolf") and Vos ("Fox") by Anna M. Louw); Corlia Fourie's short story "Wolf-se-vrou, mevrou doktor Wolf en me.Wolf" ("Wolf 's Wife, Mrs Doctor Wolf and Ms Wolf") from Liefde \& geweld ("Love \& Violence"); Alexander Strachan's novel Die jakkalsjagter ("The Jackal Hunter") and Willem Anker's Buys:'n Grensroman ("Buys: A Pioneering Novel").

Taljaard-Gilson (2018: 77) finds that the canine as a symbol "can represent the diabolic, death, the wild woman, Nazism, the dark side of the human psyche, the savage and the unconfined spirit, as well as Afrikaner identity". It was also determined that when dogs appear in their natural form within poems

the 1960s; the themes of these poems were no longer symbolic, the figurative nature of Van Wyk Louw's work changed.

13. Viljoen (2019: 142) finds that this metaphor suggests various relationships between the speaker and his writing hand; the hand as inferior to the master or the hand as faithful companion. The dog also is metaphorically connected with the speaker-as-poet in continuous pursuit of the bone of "meaning".

14. Woodward (2008: 7) uses the concept animal subjectivity in promoting the idea of animals as subjects with agency, as individual beings capable of emotions of some sorts, with moral "codes", and the ability to fear death. Sellbach (2012: 316), however, emphasises how difficult it is to interpret the "feelings' and "intentions" of animals, since no empirical evidence of their communication is known. 
and narratives, they are portrayed in a positive (compassionate) light. However, as soon as the dog appears on a figurative (allegorical) level, it usually symbolises something menacing.

Another chapter in Dogs in Southern African Literatures zooming in on the topic of dogs in an Afrikaans novel, is that of Wemar Strydom: "On queerly reading canid tropes in Eben Venter's Wolf, Wolf ("Wolf, Wolf'). He explores a reading of the canid presence and "how it can productively be read as external manifestations of affective states, notably desire, shame and exclusion" (Strydom 2018: 108). Venter's intentional blurring of boundaries, "especially within homoerotic and homosocial bonds between dog/ wolf/ jackal and man", queers the relationships presented in Venter's narrative, says Strydom (2018: 108).

Thoughts on animal subjectivity reminds us of Susan Smith's words: "Man becomes the listener, on the edge, to the voice of the natural world." "Smith 2012: 519) These are the concluding words in the article where Smith outlines the concept of ecopoetry with reference to selected poems by Martjie Bosman. Here equal attention is paid to the processes of destabilising the poem disrupting the inner coherence of the poem, creating new coherence and a new concept of home that we share with other species - and destabilising human's central position, through which we enter the role of the Other in a world shared with the non-human (Smith 2012).

Important thoughts about the Other and alternative views of this concept are found in work of Susan Meyer. In an ecocritical rereading of E. Kotze's 1983short story "Halfkrone vir die Nagmaal" ("Half-a-crown for (Holy) Communion"), ${ }^{16}$ Meyer (2015) explores Kotze's depiction of South Africa's western coastline. She finds it a literary demonstration of aspects of Mikhail Bakhtin's concept anotherness, originating from Bakhtin's theory on "relational otherness" (Meyer 2015: 100). She follows Patrick Murphy, who uses Bakhtin's model in the field of ecocriticism and describes anotherness

15. Related ideas, like the decentralisation of humankind, the reversal of the roles of (human) subject and (non-human) object, and about the agency (dynamic activity and influence) of non-human and non-living matter, all form part of the new materialism and the material ecocriticism. As said in footnote 8: These theories have a few times been used in ecocritical studies on Afrikaans literature, mainly in exploring authors' focus on humans' short-sighted and destructive dealing with nature and nature resources. Since this is the third theme of interest for ecocritical research in South Africa (as identified in the introductory section), the use of new materialism's theories in our literature needs to be examined in a follow-up study.

16. This story, originally published in 1983, was made part of the compilation titled: Diepsee: 'n Keur uit die verhale van E. Kotze in 2014, by Suzette KotzéMyburg. This omnibus contains six of Kotze's story collections in which, between 1982 and 2007, the sea and coastal strip of the West Coastline was immortalised in Afrikaans literature. 
by its key qualities: differences are respected but never used for justifying domination or impeding connections (Meyer 2015: 104). Relying on Murphy's idea that anotherness proceeds from a heterarchichal - that is, a non-hierarchical - sense of difference, Meyer spotlights Kotze's portrayal of the sea's anotherness. By voicing another nature in portraying the coast and characters relying on the resources from that coastline as their only income at the time when the story was published, Kotze opens her readers' eyes to a form of respect for another from nature as well as ideas about human connectedness to the nonhuman where principles of domination do not apply. This approach to human-nature differences very seldom was encountered in Afrikaans literature of the early 1980s (Meyer 2015: 112); sustainable inhabitation of coastal areas was fervently promoted in "Halfkrone vir die Nagmaal". The demonstration what looks like clear affinity with new materialism's principles in this story was astonishing at that time, almost four decades ago - so even before the critical approach of the new materialism was established in the USA in the late 1980s. ${ }^{17}$

Since around 2006, Meyer has identified increasing traces of a naturemindedness in Afrikaans novels corresponding with the motto in Martjie Bosman's poetry: "Man becomes the listener, on the edge, to the voice of the natural world." (Smith 2012: 519) Meyer made Petra Müller's collection of short stories, Desembers ("Decembers") (2007) and Alexander Strachan's novel Dwaalpoort (2010) (a farm's name, literally translatable as "stray gateway") part of two different studies (Meyer 2010, 2012). She points out how in these narratives, and in different ways, the authors ideate communication with the living non-human and the non-living, mostly by means of sensory awareness and by embracing the voices of silence - a concept used by Merleau-Ponty (Westling 1973: 38) - beyond the scope of human language.

Müller's stories are explored using the framework of Hubert Zapf's theory about literature as cultural ecology. ${ }^{18}$ Serenella Iovino - internationally

17. The theoretical movement of the new materialism was initiated by the so called "material turn", opposing the "linguistic turn" that was grounded in the view that language constructs reality. Before 1980 the academic world had been focusing largely on language and on its power to constitute reality, our social world and the structures that we as humans inhabit. Smith (2014b: 750) concisely explains the turning of this tide: "(Although) it was argued that language defines our world by providing us with the concepts for these structures, [...] linguistic and theoretic constitution does not account for the physical reality and materiality of life and events around us. [...] So a mattercentred approach was introduced. The new materialism as theoretical discipline led to the rethinking of materiality and to the description of matter as the substance of all things and of all material formations: human and nonhuman bodies, living and nonliving things."

18. About the naming of Zapf's concept Literature as Cultural Ecology: Zapf (2006: 55) suggests that imaginative literature can be described in its 
acknowledged ecocritic - draws attention to Zapf's influence: “As for European theoretical trends [...], I believe that Zapf's idea of literature as cultural ecology can be considered as the most elaborate and structured form of current ecocritical theory in our continent." (Iovino 2010: 118)

Meyer starts with a thorough explanation of Zapf's theoretical principles, highlighting the concept of reintegrative interdiscourse: a specific function of imaginative literature pertaining the reintegration of the excluded - by convention and cultural practice - with the cultural reality system, or enclosing the kept apart dimension of nature in the sphere of culture (Zapf 2006: 55-56, see Meyer 2010: 47). She then applies Zapf's principles to the interpretation of selected stories in Desembers. She identifies the author's intense listening to messages beyond human perception in these stories as a first step towards integrating the excluded voices of silence in the sphere of culture - to be done by means of creating stories/art (Meyer 2010: 47). Meyer finds that objects from nature in these stories are reconstructed by processes of imagination, and by the transcendence of reality, to symbols of the author's (cultural) activity (Meyer 2010: 47-51). She unravels how Müller's stories function as part of the reintegrative interdiscourse, or the reintegration of the excluded dimension of nature with the cultural reality system.

The second-mentioned study includes Meyer's analysis of the human-nature discourse in Dwaalpoort, with events situated on a farm where cattle farming made way for game capturing and hunting safaris. The story is told from the perspectives of six different characters: five human characters and Mhlophe, the leader of the troupe of white hartebeest (Alcelaphus busela-phus), which in the novel represents the primal spirit of nature. Mhlophe has the first and the final word in the novel, an authoritative voice between those speaking in between. In analysing the shared voices on Dwaalpoort Meyer effectively utilises the theoretical concept of ecological discourse and relies on the theoretical ideas that Matthew Teorey deduced from the work of the American nature writer, Craig Childs. She identifies and explores aspects of ecological discourse in Strachan's novel, and in doing so the real implication of the novel's motto is exposed. The words in this motto comes from Rentia, the farm owner of Dwaalpoort: "Ons het nie ons eie stemme nie [...]. Dis Dwaalpoort wat deur ons almal praat." / We don't have our own voices, [...] Dwaalpoort is speaking through all of us." Meyer critically enquires into the implications of the silencing of human voices in this novel. She finds that,

functional profile in such a way that it acts like an ecological principle or an ecological energy within the larger system of cultural discourses. He explains: "(L)iterature becomes the site of a constant, creative renewal of language, perception, communication, and imagination. As a metadiscursive form of textuality, it restructures the material of language and of the prevailing cultural sign systems in such a way that its forms of self-organization resemble the processes in which, in an ecological view, life organizes itself." (Zapf 2006: 55-56) Hence the naming: Literature as Cultural Ecology. 
through the ever present and cogent voice of the leader animal on this South African farm, the ongoing and all-encompassing force of nature is underlined - while the novel explicitly refers to generations of people disappearing and political systems replacing one another. This way Meyer directs the attention to the counteracting of claims in favour of subjecting animal interests to that of human in Dwaalpoort.

The ecocritic premises concerning the co-presence of and interdependence between the human and the non-human are incisively explored in an ecocritical reading of Ingrid Winterbach's last novel, Die troebel tyd ("Cloudy Times"). Meyer, the researcher again, here presents an extraordinary view on ideas associated with the other (Meyer 2019). The main character in this novel is diagnosed with depression, and Meyer's point of departure is that the portrayal of depression - still a stigmatised phenomenon in our society creates critical awareness of otherness within the human context - a human attribute as well.

Meyer's point of departure lies in third wave ecocriticism and its claim that ecocriticism explores all facets of human experience, though from an environmental viewpoint. This leads to critical questions like: What does ecocriticism mean with including "all facets of human experience"? What is the scope of the concept human and of human experience in the eyes of ecocriticism? (see Meyer 2019: 104.) Following Serenella Ioviono's approach of describing conditions of human disability or deviation from ideas about "normality", as constructed in social context, as "islands of otherness inside the human world", Meyer proceeds in exploring the main character's wilderness of the mind (Meyer 2019: 111-114). This yields great insights into the nature of humanness - especially during the character's episodes of attention on phenomena in the natural world, including wondering at the behaviour of whales and developing a mystical tie with them. Exploring the "wild" inner spaces of humanity and the special ties between different forms of life in Die troebel tyd leads to realising the impossibility of differentiating clearly between the idea of human and supposedly opposite concepts like nonhuman (Meyer 2019: 122). This article contributes to Iovino's argument that otherness is not a concept exclusively related to the non-human, but is part of human experience just as well.

Scrutiny of human-nature representations in the Afrikaans literature has brought ecocritics to discover human ties of varying nature with an interesting chain of the living non-human: birds (dove, hadedah), antelope (hartebeest), mammals (dog and canines, whale), insects, some forms of life in the ocean.

Now the attention shifts. It is turned to investigating ecocritics' attempts to analyse Afrikaans authors' understanding of our human lives with respect to the non-living in the immense and varying landscapes of our country. This will add to fully understand the contribution made by Afrikaans literature - in terms of an answer to the question of what, and to what extent, non- 
Anglophone ecocritical studies actually have added to "the understanding of the human relationship to the planet" (Adamson and Slovic (2009: 6).

\section{Theme Two: Natural Surroundings as an Intimate Personal Place}

The concept of landscape, like that of place, contains the idea of a construction - as undifferentiated space is observed, is assigned meaning by various forms of human interaction, and is endowed with value. ${ }^{19} \mathrm{I}$ go along with the idea that space is transformed into place, and geographical space into landscape by "the cultural process of imagining, seeing, historicizing and remembering" Darian-Smith (1996: 3). Environments mediated by human observation and experience, as portrayed in Afrikaans literature, include the full scope of our geographic composition: from desert dunes to places filled with the sounds of rivers and streams.

Two Afrikaans novels with spatio-temporal settings in arid areas - a desert as well as a tropical environment but in a time of severe drought, respectively - are the objects of Susan Meyer's ecocritical study of Christoffel Coetzee's Toewaaisand ("Sand Covering Everything") (2003) and Chris Barnard's Boendoe ("Wilderness") (1999). The geographical settings in these novels are areas almost untouched and unspoilt by human interference - the depths of the Namib Desert (Toewaaisand), and an isolated part of northern KwazuluNatal, bordering Mozambique (Boendoe).

Axel Goodbody reminds us that in the largely domesticated environment of the European continent, "wilderness is less important than pastoral" (reported by Flys 2010: 118). Goodbody immediately points out that it is problematic to generalise about this difference, since some issues in eco-criticism are

19. The definitions of landscape and place contain quite similar components. In re-evaluating the meaning of landscape in the context of its historical development and its changing cultural and linguistic frames, Werner Bigell (2014: 102) describes landscape as a term for framing dynamic human relations with their specific environments. In Bigell's definition the fundamentals of earlier definitions are recovered, like that of Cosgrove (1998: 13) "landscape is the external world mediated through subjective human experience" - and that of Darian-Smith (1996: 3), who views landscape as a construct out of material (geographic) elements and through human's shaping perception.

Place, according to Buell (2005: 145), is "space [...] marked as humanly meaningful through personal attachment, social relations, and physiographic distinctiveness". Goodbody and Junquera (2016: 17) confirm this description by defining sense of place as "an openness to appreciate the characteristic features of a place, whose understanding may give insight into how people interact with their environment". 
addressed in different ways in different European countries and in different parts of the world: "Debates are shaped by different geographical conditions and collective experiences, besides cultural traditions." (Goodbody, reported by Flys 2010: 118).

In Meyer's investigation into the novels of Coetzee and Barnard, she examines the intensity and the tenseness of the relationships between characters and landscapes with barely a trace of human intrusion. The main character in Boendoe is an ecologist; the immediate area he is situated in, does not show sighs of human population, power lines, reservoirs, railway lines or roads. He becomes witness to a prolonged drought that drives starving people from Mozambique to a South African mission post not too far, where he starts lending the (small and traumatised) medical staff a hand. In Toewaaisand the central figure loses the girl he loves in the dunes outside a remote settlement, Aib, in the inhospitable south-western part of the Namib. A sandstorm wipes out her tracks. The geographical extremes and challenges in these novels conjugate with environmental forces, leading to the trauma, physical and mental exhaustion of the ones left behind - suspected of not being attentive enough to the girl's movements - and to the disruption of their lives.

A completely different angle of approach is selected to explore the humandesert-interaction in Meyer (2008) close inspection of Willem D. Kotzé's autobiographic works Kalahari-kind ("Child of the Kalahari", 2003) and Kalaharijoernaal ("Journal of the Kalahari" 2006) from an autoethnographic perspective. This approach divulges much about the Kalahari people's cultural identity early in the 20's. The researcher's focus is on human identity influenced by desert surroundings by approximately 1930-1950; her theoretical base is Michell Thomashow's ideas on ecological community identity - the conviction shared by a community about the collective role they play in relation to the natural systems they depend on (Thomashow 1995: 19). Meyer finds that in Kotzé youth he was part of a desert farm colony with a unique ecological community identity, influenced largely by their nature conditions and nature oriented way of living: the harsh seasons, geographical isolation, extreme temperatures, and everybody's intimate contact with the veld (Meyer (2008: 209).

Where nature functions as an identity-shaping force it underlines how nonliving parts of nature are experienced as intimate personal places. In different but equally convincing studies Meyer heads for exploring narratives that offer verification of the intimate effects, even on psychological domain, which nature surroundings may have on individual lives and identities.

Rivers seem to be of much interest in Afrikaans literary portrayal of these intimately personal effects, including identity construction. This is affirmed by Meyer's ecocritical reading of works of either fictional and autographic nature. Met 'n eie siekspens ("With My Own Sixpence"), Engela van Rooyen's collection of youth memories from the Orange river valleys (1994), reveals a complex human-river relationship in which elements of devotion collide with 
those of enslavement. Meyer (2006a: 51) finds that the values and philosophy of life the river teaches the inhabitants of its lower valleys are core components of their identities. In Manaka: Plek van die horings ("Manaka Place of Horns", 2005) by Pieter Pieterse, the central figure's dream of a life on a boat on the Zambezi is found to be part of his identity, in that it embodies selfrealisation and has directed his thinking and self-image since childhood.

With Meyer's ecocritical interpretation of Karretjiemence (2013) (My Children Have Faces, 2013) by Carol Campbell she sharply focusses the novel's socio-political context. The family on the donkey cart ("karretjiemense") - a poor, nomadic family, continuously travelling on their cart through the semi-desert Karoo - are descendants of the San and Khoi people, as taken from Mike de Jongh's Roots and Routes: Karretjie People of the Great Karoo (2012) (Meyer 2014: 7). Meyer argues the importance of the links between the characters' self-worth and sense of belonging - components of personal identity - and their relationship with nature, read within context of the debate on "belonging and the self in nature" in the postcolonial South African era (Steenkamp 2011: 23, reported by Meyer 2014: 8). In this debate questions of place and displacement are central, as a consequence of our history characterised by segregation, land disputes, forced removals and dispossession. Karretjiemense sheds light on self-experiences in relation to the natural world, of those who possibly may have problematic experiences concerning their connections with land, resulting from our colonial past (Meyer 2014: 8). ${ }^{20}$

In spite of the negative, socially constructed identity of the "karretjie"characters that results from their homelessness, illiteracy and low social standing, that none of these family members is depicted without self-worth and self-respect (Meyer 2014: 11). Meyer provides evidence from the novel that, through their individual interaction with and response to elements of nature in the semi-desert Karoo, each one discovers his/her own value and own qualities contributing to self-respect (Meyer 2014: 11-16). In demonstrating each character's clear sense of belonging to the earth and the Karoo, and read against the socio-political background of our times, Karretjiemense offers a surprising alternative to the depiction of identity issues by means of accentuating the problematic concept of environmental belonging within the postcolonial context.

Demonstrated in this section is the scope of ecocritical findings on the thematic phenomenon of nature as an intimate personal place in Afrikaans narrative art. A broad scope of interactive links with the non-living surroundings are portrayed, and perceptions changing from awe to tense relations and to close and intimate ties with the landscapes of South Africa.

20. Meyer (2014: 9) also gives a reasoned and quite relevant exposition of the issue of authenticity in portraying the "karretjie"-characters' reality, since the author does not share the cultural and social context of these characters. 


\section{In Conclusion}

This article aimed to analyse and interpret a section of the ecocritical research on Afrikaans narrative literature. In doing so I joined the debate about the expansion of ecocritical studies to include a wider environmentally oriented world of research than the one dominated by Anglophone literatures. This article offers a critical-descriptive overview of how Afrikaans ecocritical practice lays bare the diversity and the nature of place-based themes in Afrikaans narratives. The two most prominent and extensively researched of these themes were targeted and a follow-up study is foreseeable.

Substantial proof has been found of Afrikaans literary critics' convincing contributions to "the understanding of the human relationship to the planet" (Joni Adamson and Scott Slovic (2009: 6). These contributions were analysed in order to also evaluate the various approaches and theoretical angles made use of, when considered within the broader theoretical discourse of ecocriticism. This study aids my understanding of the significance of Afrikaans ecocritics' efforts conducive to the development of the South African ecocritical discourse in general - as done from within the smaller, included sphere of Afrikaans narrative art, in adding nuances to and in amplifying thematic matters regardless the language of practise.

Ecocritics working at place-centred narratives in Afrikaans do not claim their attention to be focused on unique or never chronicled experiences concerning living and non-living nature surroundings in this tremendous South African region. The emphasis rather is on the dynamic presence of a small number of Afrikaans ecocritics keenly revealing the vitality of Afrikaans literature's voice and the abundance of narrative texts to consider in ecocritical study. In supplementing the predominant ecocritical voice of English, Afrikaans's contribution counts for the courageous scope of interpretations - referred to as the shades of meaning brought by ecocritical interpretations of Afrikaans narratives of place - as well as the scope of theoretical angles of approach demonstrated in these interpretations. This study underscores the increasing awareness of the importance of valuing and integrating ecocritical work from different language and cultural contexts within the broad scope of ecocritical theorising.

\section{References}

Adamson, J \& Slovic, S.

2009 Guest Editors' Introduction: The Shoulders We Stand On: An Introduction to Ethnicity and Ecocriticism. MELUS 34(2): 5-24. Online: DOI: [10.1353/mel.0.0019].

Bakhtin, M.M.

1984 Problems of Dostoevsky's Poetics. (Translated: C. Emerson). Minneapolis: University of Minnesota Press. 
Barendse, J.M.

2016 Die "grense van menswees" en insekwording in Willem Anker se toneelstuk Samsa-masjien. LitNet Akademies 13(3): 2-25.

Bürger, P.

1992 The Decline of Modernism. (Translated: N Walker). Pennsylvania: The Pennsylvania State University Press.

Bigell, W.

2014 The Meanings of Landscape: Historical Development, Cultural

Frames, Linguistic Variation, and Antonyms. Ecozon@ 5(1): 84-103.

Online: <https://core.ac.uk/download/pdf/58910434.pdf>.

17 September 2020.

Buell, L.

2005 The Future of Environmental Criticism: Environmental Crisis and Literary Imagination. New Jersey: Blackwell.

Burger, B.

2019 "Al half dier": Objekgeoriënteerde ontologieë, gestremdheidstudies en Siegfried (Willem Anker). Tydskrif vir Letterkunde 56(2): 28-37.

Casid, J.H.

2012 Chimerical Figurations at the Monstrous Edges of Species. In: S. LeMenager, T. Shewry \& K. Hiltner (eds) Environmental Criticism for the Twenty-first Century. New York \& London: Routledge: pp. 61-84.

Childs, P \& Fowler, R.

2006[1973] The Routledge Dictionary of Literary Terms. London \& New York: Routledge.

Cloete, T.T.

1963 Op die woord af: Opstelle oor die poësie van N.P. van Wyk Louw. Johannesburg, Kaapstad and Bloemfontein: Nasionale Boekhandel.

Cosgrove, D.

1993 Social Formation and Symbolic Landscape. Madison: University of Wisconsin Press.

Crous, $\mathrm{M}$.

2016a Die hadeda as liminale dier in Kaar van Marlene van Niekerk. LitNet Akademies 13(1): 209-231.

2016 b 'n Diergerigte lesing van "Beeld van 'n jeug: duif en perd". Tydskrif vir Nederlands en Afrikaans 23(1): 32-47.

Darian-Smith, K.

1996 Introduction. In: K. Darian-Smith, L. Gunner \& S. Nuttall (eds) Text, Theory, Space: Land, Literature and History in South Africa and Australia. London \& New York: Routledge, pp. 1-9.

Deleuze, G. \& Guattari, F.

1987 A Thousand Plateaus. Minneapolis: University of Minnesota Press.

2005[1987] A Thousand Plateaus: Capitalism and schizophrenia. Translated: B Massumi. Minneapolis: University of Minnesota Press.

Flys, C.

2010 The State of Ecocriticism in Europe: Panel Discussion. Ecozon@ 1(1): 108-22. Online :

DOI: [https://doi.org/10.37536/ECOZONA.2010.1.1.329].

11 July 2020. 
Fourie, R.

2018 Duiwelsadvokate en die ekokritiek. Tydskrif vir Geesteswetenskappe 58(4-2): 1010-1014.

Garrard, G.

2012[2004] Ecocriticism. 2nd edition. Abdingdon: Routledge.

Goodbody, A. \& Junquera, C.F.

2016 Introduction. In: A Goodbody \& C.F. Junquera (eds) Sense of Place: Transatlantic Perspectives. Alcalá: Universidad de Alcalá: pp. 1-22.

Gross, A.

2012 Introductory. In: A. Gross \& A. Vallely (eds).

2012 Animals and the Human Imagination. A Companion to Animal Studies. New York: Columbia University Press: pp 1-14.

Hartman, S., Adamson J., Gaard G. \& Oppermann, S.

2020 Through the Portal of COVID-19: Visioning the Environmental Humanities as a Community of Purpose. Bifrost Online, 8 June 2020. Online:

<https://bifrostonline.org/steven-hartman-joni-adamson-greta-gaard-

Heymans, P. serpil-oppermann/>. 11 January 2021.

2011 Eating Girls: Deleuze and Guattari's Becoming-Animal and the Romantic Sublime in William Blake's Lyca Poems. Humanimalia 3(1). Online:

<https://www.depauw.edu/humanimalia/issue\%2005/heymans.html>. 4 February.

Kolinjivadi, V.

2020 This Pandemic IS Ecological Breakdown: Different Tempo, Same Song. Uneven Earth, 2 April, 2020. Online:

<https://unevenearth.org/2020/04/this-pandemic-is-ecologicalbreakdown-different-tempo-same-song/>. 11 January 2021.

Liebenberg, W.

1991 Die begrip "teken”. In: Tristia van N.P. van Wyk Louw. PhD-thesis. Johannesburg: University of the Witwatersrand.

Marais, J.L.

2020 N.P. van Wyk Louw se diere en gestaltes herbesoek: 'n Ekokritiese lesing. Tydskrif vir Geesteswetenskappe 60(2): 435-447.

Martin, J.

1999 The Jewelled Net: Towards a Southern African Theory/ Practice of Environmental Literacy. PhD-thesis.

Marvin, G, \& McHugh, S.

2014 Online-preview. Routledge Handbook of Human-Animal Studies. G Marvin \& S. McHugh (eds). Online:

$<$ https://literariness.org/wp-content/uploads/2021/03/Literariness.orgMarvin-Garry_McHugh-Susan-Routledge-Handbook-of-HumanAnimal-Studies-2014-Taylor-and-Francis_Routledge.pdf $>$. 5 October 2020.

2014 In it Together: An Introduction to Human-Animal Studies. In: G. Marvin \& S. McHugh (eds) Routledge Handbook of Human-Animal Studies. Abingdon: Routledge: pp. 1-9. 
Meyer, S.

2006a Riviere as identiteitskonstrueerders. Literator 27(3): 51-78.

2006b Wildernis en woestyn: omgewingskragte teen die mens s'n in Boendoe (Chris Barnard) en Toewaaisand (Christoffel Coetzee). Literator 27(1): 57-78.

2008 Die Kalaharimense in Willem D. Kotzé se Kalahari-kind en Kalaharijoernaal: 'n outo-etnografiese verkenning met aandag aan identiteitsbeïnvloeding deur die natuur. Stilet 20(1): 192-214.

$2010 \quad$ Natuur en (skrywende) mens: Petra Müller se verhaalkuns binne die raamwerk van letterkunde as kulturele ekologie. Tydskrif vir Letterkunde 47(1): 41-53.

2012 Stemme van agter die plaas se hek: die mens-natuur-"gesprek" in Dwaalpoort van Alexander Strachan. Tydskrif vir Geesteswetenskappe 52(2): 290-306.

2014 Ons ís mense. My kinders hét gesigte. Die natuurlike omgewing en die konseptualisering van die self in Karretjiemense (Carol Campbell). Tydskrif vir Geesteswetenskappe 54(3): 675-692.

2015 'n Alternatiewe beskouing van die natuur se andersheid in E. Kotze se kortverhaal "Halfkrone vir die Nagmaal". Tydskrif vir Letterkunde 52(2): 102-116.

2019 Wildernis van menslike belewenis. In: Die troebel tyd van Ingrid Winterbach. LitNet Akademies 16(3): 103-127.

Oppermann, S.

2012 Transnationalization of Ecocriticism.

<https://www.academia.edu/2164159/Transnationalization_of_Eco criticism>. 14 July 2020.

2018 Envisioning a New Anthroposcenario. Nano 16.

<https://nanocrit.com/issues/issue13/Envisioning-a-New-Anthropo scenario>. September 2020.

Phillips, P.F.

2017 Book Review: Axel H. Goodbody \& Carmen Flys, Junquera (eds) Sense of Place: Transatlantic Perspectives. Ecozon@ 8(1): 218-221. Online:

<https://ebuah.uah.es/dspace/bitstream/handle/10017/29840/ rese\%c3\%b1a_sense_goodbody_philips_ecozon\%40_2017.pdf?seque nce $=1 \&$ isAllowed=y>. 2 September 2020 .

Sellbach, U.

2012 The Lives of Animals: Wittgenstein, Coetzee, and the Extent of the Sympathetic Imagination. In: A, Gross \& A, Vallely (eds) Animals and the Human Imagination. A Companion to Animal Studies. New York: Columbia University Press: pp. 307-330.

Schama, S.

$1996 \quad$ Landscape and Memory. London: Fontana Press.

Smith, S.

2012

Die aard van ekopoësie teen die agtergrond van die ekokritiese teorie met verwysing na enkele gedigte van Martjie Bosman. LitNet Akademies 9(2): 500-523.

2014a Die tasbaarheid en die on(aan)tasbaarheid van literatuurteorie: ekokritiek en die nuwe materialisme, LitNet Seminars and Essays. Online: 
<https://www.litnet.co.za/poolshoogte-die-tasbaarheid-en-dieonaantasbaarheid-van-literatuurteorie-ekokritiek/>. 4 February 2021.

2014b Ekokritiek en die nuwe materialisme: 'n Ondersoek na die nuwe materialisme in enkele gedigte van Johann Lodewyk Marais uit die bundel In die bloute (2012). LitNet Akademies 11(2): 749-774.

Steenkamp, E.L.

2011 Identity, Belonging and Ecological Crisis in South African Speculative Strydom, W. Fiction. Grahamstown: Rhodes University (Thesis - PhD).

2018 On Queerly Reading Canid Tropes in Eben Venter's Wolf Wolf. In: D. Wylie \& J-M. Barendse (eds) Dogs in Southern African Literatures. Pretoria: Van Schaik: pp. 108-112.

Taljaard-Gilson, G.

2018 Symbolic Values of the Dog in Afrikaans Literature. In: D. Wylie \& JM. Barendse (eds) Dogs in Southern African Literatures. Pretoria: Van Schaik: pp. 65-79.

Taylor, N. \& Twine, R.

2014 Introduction: Locating the "Critical" in Animal Studies. In: N. Taylor $\&$ R Twine (ed.) The Rise of Critical Animal Studies: From the Margins Thomashow, M. to the Centre. Londen \& New York: Routledge: pp. 1-15.

1995 Ecological Identity: Becoming a Reflective Environmentalist. Cambridge: The MIT Press.

Van Heerden, N. \& Visagie, A.

2013 Twee dieregestaltes by NP van Wyk Louw: Raka en Die swart luiperd. Tydskrif vir Letterkunde 50(3): 106-120.

Van Rensburg, F.I.J.

1993 Van Wyk Louw: Simbolis? In: D.H. Steenberg (ed.) Simbolisme in die Afrikaanse digterlike tradisie. Potchefstroom: Department Central Publications, Potchefstroom University for Christian Higher Education.

Viljoen, L.

2019 Hand my hond: 'n Dierestudies-perspektief op verskyningsvorme van die hond in die digter se latere poësie. In: F. Galloway (ed.) Breyten Breytenbach: Woordenaar, woordnar. Pretoria: Protea Boekhuis: pp. 121-151.

Visagie, A.

2013 Pasmaatspesies, niemenslike diere en die omgewing: gedagtes oor die postkoloniale ekokritiek in Suid-Afrika. LitNet Seminars and Essays. Online: <https://www.litnet.co.za/pasmaatspesies-niemenslike-diereen-die-omgewing-gedagtes-oor-die-postkoloniale-ekokritiek/>.

2 February 2021.

Voss, T.

2012 Refracted Modernisms: Roy Campbell, Herbert Dhlomo, N.P. van Wyk Louw. In: D. Attwell \& D. Attridge (eds) The Cambridge History of South African Literature. Cambridge: Cambridge University Press: pp. 339-359. 
Weil, K.

2012 Thinking Animals. Why Animal Studies Now? New York: Columbia

Westling, L. University Press.

2006 Literature, the Environment, and the Question of the Posthuman. In: C. Gersdorf \& S. Mayer (eds) Nature in Literary and Cultural Studies. Transatlantic Conversations on Ecocriticism. Amsterdam: Rodopi; pp. $25-48$.

Wolfe, C.

2003 Animal Rites: American Culture, the Discourse of Species, and Posthumanist Theory. Chicago en Londen: The University of Chicago Press.

2010 What is Posthumanism? Minneapolis: University of Minneapolis.

Woodward, W.

2008 The Animal Gaze. Animal Subjectivities in Southern African Narratives. Johannesburg: Wits University Press.

Woodward, W, \& Lemmer, E.

2014 Figuring the Animal in Post-Apartheid South Africa. Journal of Literary Studies 30(3): 1-5.

Zapf, $\mathrm{H}$.

2006 The State of Ecocriticism and the Function of Literature as Cultural Ecology. In: C. Gersdorf \& S. Mayer (eds) Nature in Literary and Cultural Studies. Transatlantic Conversations on Ecocriticism. Amsterdam: Rodopi: pp. 49-49.

Susan Meyer

North-West University

Meyer.susan@nwu.ac.za 